\title{
PENGARUH STRUKTUR ORGANISASI TERHADAP KINERJA PEGAWAI PADA PT MEDCO E DAN P INDONESIA SUMATERA SELATAN
}

\author{
Heriyanto ${ }^{\text {1) }}$, Laila Nurfitrah Lubis ${ }^{2)}$, \& Debbie Yuari Siallagan ${ }^{3)}$ \\ 1, 2, 3 Jurusan Administrasi Bisnis, Politeknik Negeri Pontianak \\ ${ }^{1}$ email: heriyanto.radien@gmail.com \\ 2 email: ailanlubis@gmail.com \\ 3 email: ebbie.yuari@gmail.com
}

\begin{abstract}
The completion of the set organizational goals is very much determined by human performance factors and the existing system, so it is necessary to set an organizational structure with a clear division of labor. Phenomenon that occurs in carrying out work activities, usually not all employees realize the importance of their roles and responsibilities for the organizationFrom the description on the background of the problem above, the writer will analyze whether there is an influence of the organizational structure of the PT Medco $E$ and P Indonesia company on employee performance .Population in this research is all employees of PT Medco E and P Indonesia counted 75 people and all as sample.The research method used was an explanatory survey (explanatory). To reveal the influence of independent variables and dependent variables using quantitative methods and this research hypothesis is analyzed statistically, where the independent variable (independent) is analogized into X namely Organizational Structure and the dependent variable (dependent) is analogized into $Y$ namely Employee Performance. The result of the data analysis is the score of Fcount 25.459 and the score of Ftable 3.97 with a significance score 0.000. This means that the score of Fcount> Ftable and sig $<0.05$ so it can be concluded that $H 1$ is accepted. It means that there is an influence between the variables of Organizational Structure on Employee Performance and the conclution of this research is the application of job specialization, Departmentalization, Chain of Command, Span of Control, Centralization / Decentralization and Formalization, in the organizational structure has implications for improving employee performance at PT Medco E and P Indonesia South Sumatra.
\end{abstract}

Keywords: Human, Organizational structure, And Employee Performance

\section{PENDAHULUAN}

PT Medco E Dan P Indonesia merupakan salah satu unit usaha PT Medco Energi Internasional yang bergerak di bidang eksplorasi dan produksi minyak dan gas bumi. Sejalan dengan penerapan kebijakan dan strategi sumber daya manusia yang tepat serta kerjasama tim dalam rangka mencapai tujuan perusahaan untuk meningkatkan motivasi dan kualitas terhadap hasil kerja maka diperlukan kerja keras dan komitmen dari pekerja dan perusahaan.

Tugas dan tanggung jawab yang besar dalam melakukan aktivitasnya dapat memberi pengaruh positif maupun negatif terhadap diri pekerja (Fitriana, Yulianto, \& Solikhah, 2019). Kecenderungan ini berdampak pada motivasi dan kinerja pekerja. Mewujudkan sumber daya manusia yang berdaya saing tinggi dan memiliki kinerja yang baik merupakan komponen 
penting dalam meningkatkan kinerja perusahaan secara keseluruhan. Perusahaan menginginkan seluruh karyawan dapat bekerja sesuai standar dan target yang telah ditetapkan. Oleh karena itu dibutuhkan suatu pengukuran kinerja sehingga aktifitas pekerja dapat dikontrol dan dikembangkan agar dapat mendukung strategi perusahaan dalam meningkatkan produktifitasnya. Salah satu tantangan bagi perusahaan dalam menciptakan keunggulan yakni mampu menjalankan kegiatan perusahaan secara efektif dan efisien. Pengukuran kinerja yang dilakukan oleh PT Medco E dan P Indonesia yakni menggunakan metode penilaian tampilan kerja yang telah digunakan sejak tahun 2005 yakni Perfomance evaluation (evaluasi kinerja). Kebutuhan penilaian kerja tersebut sejalan dengan dibutuhkannya suatu alat ukur yang dapat membantu perusahaan untuk mengetahui kinerja pekerja yang tentunya berimplikasi pada target dan sasaran yang telah ditetapkan perusahaan. Dengan struktur organisasi yang sudah ada serta dipercayakannya sejumlah pegawai untuk menjalankan kegiatan perusahaan membawa suatu harapan pada perubahan pola kerja ke arah yang lebih baik yang bisa dibuktikan dengan kinerja yang baik. Terselesaikannya tujuan organisasi yang ditetapkan sangat ditentukan oleh faktor kinerja manusia dan sistem yang ada sehingga perlu di atur struktur organisasi dengan pembagian kerja yang jelas. Fenomena yang terjadi di dalam melakukan aktivitas pekerjaan, biasanya tidak semua pegawai menyadari pentingnya peran dan tanggung jawab mereka bagi organisasi. Dari uraian pada latar belakang masalah di atas maka penulis akan menganalisis apakah ada pengaruh struktur organisasi pada perusahaan PT Medco E dan P Indonesia terhadap kinerja pegawai.

\section{KAJIAN LITERATUR}

Definisi organisasi banyak ragamnya, tergantung pada sudut pandang yang dipakai untuk melihat organisasi. Organisasi dapat dipandang sebagai wadah, sebagai proses, sebagai perilaku dan sebagai alat untuk mencapai tujuan. Namun demikian, definisi organisasi yang dikemukakan oleh para ahli organisasi sekurang - kurangnya ada unsur sistem kerjasama, orang yang bekerjasama dan tujuan bersama yang hendak dicapai.

Siagian,

(1997:

138-141)

mendefinisikan organisasi sebagai berikut :

"Organisasi adalah setiap bentuk perserikatan antara dua orang atau lebih yang bekerja sama untuk tujuan bersama dan terikat secara formal dalam persekutuan mana selalu terdapat hubungan antara seorang atau sekelompok orang disebut pimpinan dan seorang atau sekelompok orang lain disebut bawahan".

Gibson, (1987:5) berpendapat bahwa ciri khas organisasi tetap sama, yaitu perilaku terarah dan tujuan. Gibson dan kawan-kawan berpendapat bahwa "Organisasi itu mengejar tujuan dan sasaran yang dapat dicapai secara efisien dan efektif dengan tindakan yang dilakukan secara bersama- sama“.

Pengertian organisasi ditinjau dari beberapa sudut pandang, antara lain:

\section{a. Organisasi sebagai wadah}

Organisasi dipandang sebagai wadah mencerminkan bahwa organisasi merupakan tempat dijalankannya aktivitas administrasi dan manajemen. 


\section{b. Organisasi sebagai proses}

Organisasi dipandang sebagai proses mencerminkan kedinamisan aktivitas kerja dalam organisasi.

\section{c. Organisasi sebagai suatu sistem}

Perilaku Organisasi dipandang sebagai suatu perilaku apabila organisasi tersebut lebih dinamis bila dibandingkan dengan organisasi sebagai proses ataupun sebagai wadah. Organisasi sebagai suatu sistem perilaku, didalamya tercakup input, proses, dan output. Input berupa sekumpulan orang, proses berupa interaksi masingmasing atau antar personel yang terlibat dalam organisasi tersebut dan output berupa hasil kerja sama dalam melaksanakan sesuatu untuk mencapai tujuan yang sama.

d.Organisasi sebagai alat untuk mencapai tujuan

Organisasi disini sebagai alat untuk meringankan, mengefektifkan, mengefisienkan, dan mengoptimalkan, pencapaian tujuan yang hendak dicapai bersama dengan cara kerja bersama- sama.

\section{Konsep struktur organisasi}

Struktur organisasi merupakan salah satu faktor yang berpengaruh terhadap kinerja organisasi publik, Robbins, (1994:40) yang mengemukakan pendapatnya mengenai dimensi struktur organisasi yaitu kompleksitas, formalitas, dan desentralisasi.

Robbin mendefinisikan suatu struktur organisasi terdapat enam unsur kunci struktur organisasi antara lain :

\section{a. Spesialisasi kerja}

Spesialisasi kerja merupakan pembagian bidang kerja yaitu sampai tingkat mana tugas dalam organisasi dipecah-pecah menjadi pekerjaan terpisah-pisah sesuai dengan kebutuhan, pendidikan, pengalaman dan keterampilan yang dimiliki pegawai.

\section{b.Departementalisasi}

Departementalisasi merupakan dasar yang dipakai dalam pengkelompokan pelaksanaan tugas pada masing - masing individu, jenis pekerjaan dan jabatan guna pencapaian tujuan organisasi.

\section{c. Rantai komando}

Rantai komondo merupakan garis wewenang yang tidak terputus putus yang terentang dari top manajemen ke eselon terbawah dan memperjelas siapa melapor kesiapan

\section{d. Rentang kendali}

Rentang kendali merupakan jumlah bawahan yang dapat diatur manajemen secara efektif dan efisien sehingga organisasi dapat bekerja seoptimal mungkin

\section{e. Sentralisasi/Desentralisasi}

Sentralisasi/Desentralisasi

merupakan tingkat dimana pengambilan keputusan dipusatkan pada titik tunggal dalam organisasi, atau sebaliknya pada tingkat mana wewenang pengambilan keputusan dapat diserahkan kepada tingkat yang lebih rendah.

\section{f. Formalisasi}

Formalisasi merupakan tingkat mana pekerjaan dalam organisasi di bakukan.

\section{Konsep Kinerja}

Pengertian Kinerja berasal dari kata job performance atau actual performance yang berarti prestasi kerja atau prestasi sesungguhnya yang dicapai oleh seseorang. Pengertian kinerja (prestasi kerja) adalah hasil kerja secara kualitas dan kuantitas yang dicapai oleh seorang pegawai dalam melaksanakan fungsinya sesuai dengan tanggung jawab yang diberikan kepadanya. Performance atau kinerja merupakan hasil atau keluaran dari suatu proses. (Nurlaila, 2010:71). Menurut 
pendekatan perilaku dalam manajemen, kinerja adalah kuantitas atau kualitas sesuatu yang dihasilkan atau jasa yang diberikan oleh seseorang yang melakukan pekerjaan. (Luthans, 2005:165). Kinerja merupakan prestasi kerja, yaitu perbandingan antara hasil kerja dengan standar yang ditetapkan. (Dessler, 2000:41). Kinerja adalah hasil kerja baik secara kualitas maupun kuantitas yang dicapai oleh seseorang dalam melaksanakan tugas sesuai tanggung jawab yang diberikan. (Mangkunegara, 2000). Kinerja adalah hasil atau tingkat keberhasilan seseorang secara keseluruhan selama periode tertentu dalam melaksanakan tugas dibandingkan dengan berbagai kemungkinan, seperti standar hasil kerja, target atau sasaran atau kriteria yang telah ditentukan terlebih dahulu telah disepakati bersama. (Rivai, 2005:50).

Sedangkan Mathis \& Jackson, 1976:65) menyatakan bahwa kinerja pada dasarnya adalah apa yang dilakukan atau tidak dilakukan pegawai. Manajemen kinerja adalah keseluruhan kegiatan yang dilakukan untuk meningkatkan kinerja perusahaan atau organisasi, termasuk kinerja masing-masing individu dan kelompok kerja di perusahaan tersebut. Dari tingkah laku. (Armstrong, 1990:15). Pengertian kinerja ini mengaitkan antara hasil kerja dengan tingkah laku. Sebgai tingkah laku, kinerja merupakan aktivitas manusia yang diarahkan pada pelaksanaan tugas organisasi yang dibebankan kepadanya Faktor-faktor yang Mempengaruhi Kinerja

\section{a. Efektifitas dan efisiensi}

Bila suatu tujuan tertentu akhirnya bisa dicapai, kita boleh mengatakan bahwa kegiatan tersebut efektif tetapi apabila akibatakibat yang tidak dicari kegiatan menilai yang penting dari hasil yang dicapai sehingga mengakibatkan kepuasan walaupun efektif dinamakan tidak efesien. Sebaliknya, bila akibat yang dicaricari tidak penting atau remeh maka kegiatan tersebut efesien. (Prawirosentono, 1999:27).

\section{b. Otoritas (wewenang)}

Otoritas menurut adalah sifat dari suatu komunikasi atau perintah dalam suatu organisasi formal yang dimiliki seorang anggota organisasi kepada anggota yang lain untuk melakukan suatu kegiatan kerja sesuai dengan kontribusinya. (Prawirosentono, 1999:27). Perintah tersebut mengatakan apa yang boleh dilakukan dan yang tidak boleh dalam organisasi tersebut.

\section{c. Disiplin}

Disiplin adalah taat kepda hukum dan peraturan yang berlaku (Prawirosentono, 1999:27) Jadi, disiplin karyawan adalah kegiatan karyawan yang bersangkutan dalam menghormati perjanjian kerja dengan organisasi dimana dia bekerja.

\section{d. Inisiatif}

Inisiatif yaitu berkaitan dengan daya pikir dan kreatifitas dalam membentuk ide untuk merencanakan sesuatu yang berkaitan dengan tujuan organisasi.

Karakteristik Kinerja Karyawan

Karakteristik orang yang mempunyai kinerja tinggi adalah sebagai berikut (Mangkunegara, 2000:68)

1. Memiliki tanggung jawab pribadi yang tinggi.

2. Berani mengambil dan menanggung resiko yang dihadapi. 3. Memiliki tujuan yang realistis.

4. Memiliki rencana kerja yang menyeluruh dan berjuang untuk merealisasi tujuannya. 
5. Memanfaatkan umpan balik (feed back) yang konkrit dalam seluruh kegiatan kerja yang dilakukannya.

6. Mencari kesempatan untuk merealisasikan rencana yang telah diprogramkan.

Indikator Kinerja Karyawan

Indikator untuk mengukur kinerja karyawan secara individu ada enam indikator, yaitu (Robbins et al., 2008:260):

1. Kualitas. Kualitas kerja diukur dari persepsi karyawan terhadap kualitas pekerjaan yang dihasilkan serta kesempurnaan tugas terhadap keterampilan dan kemampuan karyawan.

2. Kuantitas. Merupakan jumlah yang dihasilkan dinyatakan dalam istilah seperti jumlah unit, jumlah siklus aktivitas yang diselesaikan.

3. Ketepatan waktu. Merupakan tingkat aktivitas diselesaikan pada awal waktu yang dinyatakan, dilihat dari sudut koordinasi dengan hasil output serta memaksimalkan waktu yang tersedia untuk aktivitas lain.

4. Efektivitas. Merupakan tingkat penggunaan sumber daya organisasi (tenaga, uang, teknologi, bahan baku) dimaksimalkan dengan maksud menaikkan hasil dari setiap unit dalam penggunaan sumber daya.

5. Kemandirian. Merupakan tingkat seorang karyawan yang nantinya akan dapat menjalankan fungsi kerjanya Komitmen kerja. Merupakan suatu tingkat dimana karyawan mempunyai komitmen kerja dengan instansi dan tanggung jawab karyawan terhadap kantor

\section{METODE PENELITIAN}

Dengan memperhatikan tujuan penelitian, maka metode penelitian digunakan dengan survey eksplanatori (explanatory).
Informasi atau data primer untuk penelitiann ini dihimpun melalui metode survey dengan menggunakan angket yang diisi oleh responden. Penggunaan metode ini dimaksudkan bukan hanya untuk menerangkan konsep dan fakta dan peristiwa tetapi bermaksud menganalisa dan menjelaskan pengaruh kausal antara variabelvariabel melalui pengujian hipotesis. Dengan Survey eksplanatori diharapkan akan dapat mengungkap secara cermat pengaruh struktur organisasi terhadap kinerja karyawan pada PT Medco E dan P Indonesia Sumatera Selatan. Untuk mengungkap pengaruh variabel bebas dan variabel tidak bebas menggunakan metode kuantitatif dan hipotesis penelitian ini dianalisis secara statistik.

\section{HASIL DAN PEMBAHASAN}

Analisis statistik deskriptif adalah statistik yang digunakan dalam menganalisis data dengan cara mendeskripsikan atau menggambarkan data yang telah terkumpul. Menurut Ghozali, (2009) analisis ini bertujuan untuk memberikan gambaran atau mendeskripsikan data dalam variabel yang dilihat dari nilai ratarata (mean), minimum, maksimum dan standar deviasi. Statistik deskriptif adalah statistika yang digunakan dalam mendiskripsikan data menjadi informasi yang lebih jelas serta mudah dipahami yang memberikan gambaran mengenai penelitian berupa hubungan dari variabel-variabel independen yang diproksikan dengan dewan direksi dan ukuran perusahaan. 
Hasil penelitian analisis statistik deskriptif dapat dilihat dalam tabel di bawah ini:

a. Variabel Struktur Organisasi

Tabel 1 Descriptive Statistics Struktur Organisasi

\begin{tabular}{|c|c|c|c|c|c|c|}
\hline & N & Minimum & Maximum & Sum & Mean & Std. Deviation \\
\hline X1 & 75 & 1 & 5 & 286 & 3,81 &, 881 \\
X2 & 75 & 1 & 5 & 231 & 3,08 & 1,088 \\
X3 & 75 & 1 & 5 & 305 & 4,07 &, 644 \\
X4 & 75 & 2 & 5 & 275 & 3,67 &, 684 \\
X5 & 75 & 1 & 5 & 228 & 3,04 &, 992 \\
X6 & 75 & 1 & 5 & 278 & 3,71 &, 818 \\
X7 & 75 & 1 & 5 & 271 & 3,61 & 1,089 \\
X8 & 75 & 1 & 5 & 287 & 3,83 &, 742 \\
X9 & 75 & 1 & 5 & 300 & 4,00 &, 593 \\
X10 & 75 & 1 & 5 & 306 & 4,08 &, 632 \\
\hline
\end{tabular}

b. Variabel Kinerja Karyawan

Tabel 2 Descriptive Statistics Kinerja Karyawan

\begin{tabular}{|c|c|c|c|c|c|c|}
\hline & N & Minimum & Maximum & Sum & Mean & Std. Deviation \\
\hline Y1 & 75 & 1 & 5 & 275 & 3,67 &, 890 \\
Y2 & 75 & 1 & 5 & 223 & 2,97 &, 972 \\
Y3 & 75 & 1 & 5 & 306 & 4,08 &, 712 \\
Y4 & 75 & 1 & 5 & 309 & 4,12 &, 636 \\
Y5 & 75 & 1 & 5 & 310 & 4,13 &, 600 \\
Y6 & 75 & 1 & 5 & 296 & 3,95 &, 634 \\
Y7 & 75 & 1 & 5 & 285 & 3,80 &, 771 \\
Y8 & 75 & 1 & 5 & 244 & 3,25 & 1,001 \\
Y9 & 75 & 1 & 5 & 294 & 3,92 &, 673 \\
Y10 & 75 & 1 & 5 & 278 & 3,71 &, 731 \\
\hline
\end{tabular}


Uji Validitas

Uji validitas dilakukan dengan menghitung korelasi antara skor atau butir pertanyaan dengan skor konstruk atau variable. Hal ini dapat dilakukan dengan uji signifikansi yang membandingkan $r$ hitung dengan $r$ table untuk degree of fredom $(\mathrm{df})=\mathrm{n}-\mathrm{k}$ dalam hal ini $\mathrm{n}$ adalah jumlah sampel dan $\mathrm{k}$ adalah konstruk. apabila $r$ hitung untuk $r$ tiap butir dapat dilihat pada kolom Corected Item Total Correlation lebih besar dari $r$ tabel dan nilai $r$ positif, maka butir atau pertanyaan tersebut dapat dikatakan valid. Pengujian ini dilakukan apakah kuesioner yang ada dapat mengungkapkan data-data yang ada pada variabel-variabel penelitian secara tepat. Hasil dari pengujian validitas kuesioner dapat diketahui sejauh mana data yang terkumpul sesuai dengan variabel-variabel penelitian. Untuk tingkat validitas, dilakukan uji signifikansi dengan membandingkan $r$ hitung dengan $r$ tabel untuk degree of freedom $(\mathrm{df})=$ $\mathrm{n}-\mathrm{k}$. Pada kasus ini didapat $\mathrm{r}$ tabel 0,2272 . Jika nilai $r$ Tabel $\geq$ nilai Pearson Correlation atau nilai signifikansi lebih besar atau sama dengan nilai taraf nyata 0,05 maka dapat ditarik kesimpulan bahwa butir pertanyaan dinyatakan valid. Namun jika $\mathrm{r}$ Tabel < dari nilai Pearson Correlation atau nilai signifikansi lebih kecil dari nilai taraf nayata 0,05 maka butir pertanyaan tidak valid. Hasil analisis dapat dilihat pada tabel berikut ini:

a. Variabel Struktur Organisasi

Berikut ringkasan hasil uji

validitas:
Tabel 3

Uji Validitas

\begin{tabular}{llll}
\hline Variabel & $\begin{array}{l}\mathrm{r} \\
\text { Tabel }\end{array}$ & $\begin{array}{l}\text { Pearson } \\
\text { Correlation }\end{array}$ & Keterangan \\
\hline X1 & 0,2272 & 0,459 & Valid \\
X2 & 0,2272 & 0,533 & Valid \\
X3 & 0,2272 & 0,713 & Valid \\
X4 & 0,2272 & 0,333 & Valid \\
X5 & 0,2272 & 0,439 & Valid \\
X6 & 0,2272 & 0,486 & Valid \\
X7 & 0,2272 & 0,509 & Valid \\
X8 & 0,2272 & 0,545 & Valid \\
X9 & 0,2272 & 0,591 & Valid \\
X10 & 0,2272 & 0,553 & Valid \\
\hline
\end{tabular}

b. Variabel Kinerja Karyawan

Berikut ringkasan hasil uji

validitas:

Tabel 4

Uji Validitas

\begin{tabular}{llll}
\hline Variabel & r Tabel & $\begin{array}{l}\text { Pearson } \\
\text { Correlation }\end{array}$ & Keterangan \\
\hline Y1 & 0,2272 & 0,000 & Valid \\
Y2 & 0,2272 & 0,234 & Valid \\
Y3 & 0,2272 & 0,745 & Valid \\
Y4 & 0,2272 & 0,774 & Valid \\
Y5 & 0,2272 & 0,801 & Valid \\
Y6 & 0,2272 & 0,708 & Valid \\
Y7 & 0,2272 & 0,651 & Valid \\
Y8 & 0,2272 & 0,340 & Valid \\
Y9 & 0,2272 & 0,628 & Valid \\
Y10 & 0,2272 & 0,626 & Valid \\
\hline
\end{tabular}

Penjelasan

Dari dua tabel 3 dan 4 diatas terlihat bahwa nilai $r$ hitung pada kolom corrected item-total correlation untuk masing-masing item memiliki rhitung lebih besar dan positif dibanding $r$ tabel, dengan uji satu sisi didapat $r$ tabel sebesar 0,2272, maka dapat disimpulkan bahwa semua indikator dari kedua variabel $\mathrm{X}$ dan $\mathrm{Y}$ adalah valid. 


\section{Uji Reliabilitas}

Ghozali ( 2011:47 ) Uji Reliabilitas digunakan untuk mengukur suatu kuesioner yang merupakan indikator dari variabel. Untuk mengukur reliabilitas dengan menggunakan uji statistik adalah Cronbach Alpha $(\alpha)$. suatu variabel dikatakan reliabel jika memiliki Cronbach alpha lebih dari 0,60 ( > 0,60). Untuk menguji reliabilitas instrumen, maka menggunakan analisis SPSS. Adapun hasil pengujian reliabilitas dapat

\section{Tabel 5}

\section{Reliability Statistics}

\begin{tabular}{|l|l|}
\hline $\begin{array}{l}\text { Cronbach's } \\
\text { Alpha }\end{array}$ & N of Items \\
\hline 0,664 & 10 \\
\hline
\end{tabular}

dilihat pada tabel berikut ini:

a. Variabel Struktur Organisasi

Berdasarkan tabel 5 Reability Statistics dapat uji Reabilitas dengan Cronbach's Alpha dengan nilai 0,664 lebih besar dari nilai 0,6 maka dapat disimpulkan bahwa data secara keseluruhan pada variabel struktur organisasi reliabel atau konsisten.

b. Variabel Kinerja Karyawan

Tabel 6 Reliability Statistics

\begin{tabular}{|l|l|}
\hline $\begin{array}{l}\text { Cronbach's } \\
\text { Alpha }\end{array}$ & N of Items \\
\hline 0,777 & 10 \\
\hline
\end{tabular}

Berdasarkan tabel 6 Reability Statistics dapat uji Reabilitas dengan Cronbach's Alpha dengan nilai 0,777 lebih besar dari nilai 0,6 maka dapat disimpulkan bahwa data secara keseluruhan pada variabel struktur organisasi reliabel atau konsisten.

Maka Dari dua tabel diatas dapat diketahui bahwa masing-masing variabel memiliki nilai cronbach alpha lebih dari $0,60 \quad(\alpha>0,60)$, sehingga dapat disimpulkan bahwa semua variabel $\mathrm{X}$ dan $\mathrm{Y}$ adalah reliabel dan angket tersebut dapat digunakan sebagai alat pengumpul data

\section{Uji Normalitas}

Uji normalitas untuk mengetahui apakah variabel dependen, independen atau keduanya berdistribusi normal, mendekati normal atau tidak. Model regresi yang baik hendaknya berdistribusi normal atau mendekati normal (Umar, 2008: 181). Uji yang digunakan adalah menggunakan Kolmogorov-Smirnov Test. Jika nilai signifikansi dari uji Kolmogorov-Smirnov>5\%,maka residual berdistribusi normal.

Tabel 7

One-Sample Kolmogorov-Smirnov Test

\begin{tabular}{|cc|c|}
\hline & & $\begin{array}{c}\text { Unstandardized } \\
\text { Residual }\end{array}$ \\
\hline \multicolumn{2}{|c|}{$\mathrm{N}$} & 75 \\
Normal $^{\text {Parameters }}{ }^{\mathrm{a}, \mathrm{b}}$ & Mean & Std. \\
& Deviation & 3.84557390 \\
Most Extreme & Absolute & .102 \\
Differences & Positive & .066 \\
& Negative & -.102 \\
Kolmogorov-Smirnov Z & .879 \\
Asymp. Sig. (2-tailed) & .422 \\
\hline
\end{tabular}

a. Test distribution is Normal.

b. Calculated from data.

Berdasarkan hasil uji normalitas menggunakan aplikasi statitistik IBM SPSS Versi 23.0 pada Tabel 7 di atas diperoleh nilai uji Kolmogorov-Smirnov $>0,05$ yaitu 0,987 sehingga dapat disimpulkan bahwa data penelitian ini berdistribusi normal.

\section{Uji Multikolinearitas}

Uji multikolinieritas untuk mengetahui apakah pada model regresi ditemukan adanya korelasi antarvariabel independen. Jika terjadi korelasi, terdapat masalah multikolinieritas yang harus diatasi (Umar, 2008: 177). Uji ini dilihat dari nilai tolerance dan VIF (Variance 
Inflation Factor) dengan ketentuan sebagai berikut:

1. Jika nilai tolerance $>0,1$ dan nilai VIF (Variance Inflation Factor) < 10, maka dapat disimpulkan bahwa tidak terjadi multikolinearitas antar variabel independennya dalam model regresi.

2. Jika nilai tolerance $<0,1$ dan nilai VIF (Variance Inflation Factor) > 10, maka dapat disimpulkan bahwa terjadi multikolinearitas antar variabel independennya dalam model regresi.

Tabel 8

Uji Multikolinearitas

\begin{tabular}{|c|c|c|c|c|c|c|c|}
\hline \multirow[b]{2}{*}{$\begin{array}{l}\text { Mode } \\
1\end{array}$} & \multicolumn{2}{|c|}{$\begin{array}{l}\text { Unstandard } \\
\text { ized } \\
\text { Coefficient } \\
\text { s } \\
\end{array}$} & $\begin{array}{c}\text { Stand } \\
\text { ardize } \\
\mathrm{d} \\
\text { Coeff } \\
\text { icient } \\
\text { s }\end{array}$ & \multirow[b]{2}{*}{$\mathrm{t}$} & \multirow[b]{2}{*}{ Sig } & \multicolumn{2}{|c|}{$\begin{array}{c}\text { Collinearity } \\
\text { Statistics }\end{array}$} \\
\hline & B & $\begin{array}{l}\text { Std. } \\
\text { Error }\end{array}$ & Beta & & & $\begin{array}{l}\text { Tole- } \\
\text { rance }\end{array}$ & VIF \\
\hline $1(\mathrm{Co}$ & 17.4 & 4.01 & & 4.3 & .00 & & \\
\hline $\begin{array}{l}\text { nsta } \\
\text { nt) }\end{array}$ & 79 & 3 & & 56 & 0 & & \\
\hline $\begin{array}{l}\text { total } \\
. X\end{array}$ & .545 & .108 & .509 & $\begin{array}{r}5.0 \\
46\end{array}$ & $\begin{array}{r}.00 \\
0\end{array}$ & 1.000 & 1.000 \\
\hline
\end{tabular}

Berdasarkan Tabel 8 di atas menunjukkan bahwa variabel $(\mathrm{X})$ memiliki hasil nilai tolerance $>0,1(1,000)$ dengan uji VIF < 10 yaitu 1,000 . Maka dapat disimpulkan bahwa pada penelitian ini tidak mengalami multikolinearitas.

\section{Uji Hipotesis}

Uji Hipotesis yang digunakan dalam penelitian ini adalah Uji Parsial (Uji Statistik t), dan Uji Signifikansi Simultan variasi variabel dependen amat terbatas. Nilai yang mendekati satu dari variabelvariabel independen memberikan hampir semua informasi yang dibutuhkan untuk memprediksi variasi variabel dependen. Jika dalam uji empiris didapat nilai adjusted R2 negatif, maka nilai adjusted $\mathrm{R} 2$ dianggap bernilai nol.

\section{Tabel 9}

Uji Koefisien Determinasi $\left(R^{2}\right)$

\begin{tabular}{|l|r|r|r|c|}
\hline & & & Adjusted \\
$\mathrm{R}$ & $\begin{array}{c}\text { Std. } \\
\text { Error of } \\
\text { the } \\
\text { Model }\end{array}$ & $\mathrm{R}$ & $\begin{array}{c}\mathrm{R} \\
\text { Square }\end{array}$ & $\begin{array}{c}\text { Square } \\
\text { Estimate }\end{array}$ \\
\hline 1 & $.509^{\mathrm{a}}$ & .259 & .248 & 3.872 \\
\hline
\end{tabular}

Sumber: Hasil Olahan SPSS 23.0 Tahun 2020

Berdasarkan Tabel 9 di atas, nilai $\mathrm{R}$ Square adalah 0,259. Jika dilihat nilai $R$ Square 0,426 di atas artinya variabel terikat yaitu Kinerja Karyawan dapat dipengaruhi oleh variabel Struktur Organisai sebesar 25,9 \%. Sehingga sisanya sebesar $74,1 \%$ dipengaruhi oleh variabel lain di luar pada penelitian ini.

\section{b. Uji Signifikansi Simultan (Uji F)}

Uji $\mathrm{F}$ yaitu suatu uji untuk mengetahui pengaruh variabel Struktur Organisasi terhadap variabel terikat yaitu Kinerja Karyawan. Jika nilai signifikansi $<0,05$ maka variabel independen berpengaruh signifikan terhadap variabel dependen. (Priyatno, 2013:48).

(Uji f). Berikut hasil uji hipotesis dibawah ini :

a. Uji Koefisien Determinasi (R2)

Koefisien determinasi digunakan untuk mengukur seberapa jauh kemampuan model dalam menerangkan variabel dependen. (Ghozali, 2011: 42). Nilai R2 yang kecil berarti kemampuan variabelvariabel independen dalam menjelaskan 
Tabel 10

Uji Simultan (Uji f)

ANOVA ${ }^{b}$

\begin{tabular}{|l|c|c|c|c|c|}
\hline Model & $\begin{array}{c}\text { Sum of } \\
\text { Squares }\end{array}$ & df & $\begin{array}{c}\text { Mean } \\
\text { Square }\end{array}$ & F & Sig. \\
\hline $\begin{array}{l}\text { Regres } \\
\text { sion } \\
\text { Residu } \\
\text { al } \\
\text { Total }\end{array}$ & 381.656 & 1 & 381.656 & 25.459 & .000 \\
a & 1094.344 & 73 & 14.991 & & \\
\hline
\end{tabular}

a. Predictors: (Constant), total.X

b. Dependent Variable: total.y

Hasil perhitungan Tabel 10 di atas didapat nilai Fhitung 25,459 dan nilai Ftabel 3,97 dengan nilai signifikansi 0,000. Hal ini berarti nilai Fhitung $>$ Ftabel dan sig $<0,05$ sehingga dapat disimpulkan bahwa H1 diterima. Artinya terdapat pengaruh antara variabel Struktur Organisasi terhadap Kinerja Karyawan.

\section{KESIMPULAN}

1. Berdasarkan hasil penelitian dan pembahasan tentang pengaruh struktur organisasi terhadap kinerja PT. Medco E dan P Indonesia Sumatera Selatan yang ditentukan oleh spesialisasi pekerjaan , Departementalisasi, Rantai Komando, Rentang kendali, Sentralisasi/Desentralisasi dan Formalisasi menunjukkan hubungan yang linier yang mengandung pengertian bahwa penerapan spesialisasipekerjaan,

Departementalisasi, Rantai Komando, Rentang kendali, Sentralisasi/ Desentralisasi dan Formalisasi, dalam struktur organisasi memberikan implikasi pada peningkatan kinerja pegawai pada PT Medco E Dan P Indonesia Sumatera Selatan.

2. Dari variabel struktur organisasi yang dideskripsikan oleh dimensi Departementalisasi, Rantai Komando, Rentang kendali, Sentralisasi / Desentralisasi dan Formalisasi didominasi oleh perhatian kesesuaian jabatan dengan pendidikan, pengalaman dan keterampilan yang dimiliki.

3. Spesialisasi pekerjaan dalam struktur organisasi dan proses belajar dan berkembang dalam kinerja meningkatkan keahlian dan kompetensi yang terlihat dari adanya kesesuaian jabatan dengan pendidikan, pengalaman dan keterampilan pegawai.

\section{DAFTAR PUSTAKA}

Armstrong, M. (1990). Manajemen sumberdaya manusia. PT. Elex Media Komputindo, Jakarta.

Fitriana, R., Yulianto, A., \& Solikhah, B. (2019). Are characteristics of sharia supervisory boards able to improve the performance of islamic banking? Journal of Islamic Accounting and Finance Research, 1(1), 1. https://doi.org/10.21580/jiafr.2019.1 .1 .3753

Ghozali, I. (2009). Aplikasi analisis multivariate dengan program spss.

Ghozali, I. (2011). Aplikasi analisis multivariat dengan program spss. Badan penerbit Universitas Diponegoro.

Gibson, J. L. (1987). Organisasi: Perilaku, struktur, proses., Terj. Ninuk Adriani. Penerbit Erlangga.

Luthans, F. (2005). Organizational Behavior. McGraw-Hill.

Mangkunegara, A. A. A. P. (2000). Manajemen sumber daya manusia perusahaan. Remaja Rosdakarya.

Mathis, R. L., \& Jackson, J. H. (1976). Personnel: $\quad$ Contemporary Perspectives and Applications. West Publishing Company.

Nurlaila. (2010). Manajemen sumber daya manusia. Lepkhair.

Prawirosentono, S. (1999). Manajemen sumberdaya manusia: Kebijakan kinerja karyawan: kiat membangun organisasi kompetitif menjelang perdagangan bebas 
dunia. Badan Penerbit Fakultas Ekonomi (BPFE).

Priyatno, D. (2013). Mandiri belajar analisis data dengan spss. Mediakom.

Rivai, V. (2005). Performance appraisal: Sistem yang tepat untuk menilai kinerja karyawan dan meningkatkan daya saing perusahaan. PT RajaGrafindo Persada.

Robbins, S. P. (1994). Teori Organisasi: Struktur, Desain \& Aplikasi. Terj. Jusuf Udaya. Arcan.

Robbins, Stephen P, Judge, \& Timothy A. (2008). Perilaku Organisasi. Salemba Empat.

Siagian, S. (1997). Teori pengembangan organisasi. Aksara.

Umar, H. (2008). Metode penelitian untuk skripsi dan tesis bisnis. PT RajaGrafindo Persada. 